\section{Vegetative Compensation Response of a Procumbent Grapevine (Vitis vinifera cv. Syrah) Cultivar under Mechanical Canopy Management}

\author{
S. Kaan Kurtural ${ }^{3}$, Lydia F. Wessner ${ }^{1}$, and Geoffrey Dervishian ${ }^{2}$ \\ Department of Viticulture and Enology, California State University 2360 \\ E. Barstow Avenue M/S, Fresno, CA 93740
}

Additional index words. dormant pruning, production efficiency, shoot thinning, warm climate viticulture

\begin{abstract}
A trial in the San Joaquin Valley of California investigated how the interaction of pruning systems and mechanical shoot thinning affected canopy performance, yield components, fruit phenolic composition at harvest, and production efficiency of a procumbent cultivar in a warm climate grape-growing region. Two pruning systems and three shoot thinning treatments were arranged factorially in a randomized complete block design with four replications. The pruning methods were applied by either handpruning to a target of 25 nodes/m or mechanically hedging and retaining a $100-\mathrm{mm}$ spur height. The shoot density treatments were applied mechanically at a modified EichhornLorenz scale, stage 17 to retain 40 or 45 shoots/m of a row, or left unthinned. The contribution of count shoots to total shoots increased when mechanical box pruning replaced spur pruning. The contribution of percent count shoots to total shoots was greatest with 40 shoots $/ \mathrm{m}$ and unthinned treatments. The percent photosynthetically active radiation $(P A R)$ transmission and percent canopy gaps increased with mechanical box pruning and also with the decrease in shoot density per meter of row. Berry and cluster size decreased with mechanical box pruning application. However, because mechanically box-pruned vines carried more clusters, yield per meter of row increased. There was a quadratic response to shoot thinning where berry skin phenolics, anthocyanins, and tannins decreased with the 45 shoots/m treatment when compared with 40 shoots/m and unthinned treatments. Pruning weight per meter of row and leaf area-tofruit ratio decreased, whereas Ravaz Index (kg yield/kg pruning weight) increased with mechanical box pruning. Shoot thinning treatments did not affect pruning weight per meter of row or leaf area-to-fruit ratio. Increasing amount of $P A R$ and percent canopy gaps by shoot thinning resulted in vegetative compensation from a sparsely populated grapevine canopy, thereby negating its purported effects. The 40 and $45 \mathrm{shoots} / \mathrm{m}$ treatments repopulated the canopy rapidly with non-count shoots thereby increasing the pruning weight per meter of row at the end of the season. In the absence of a physiological response, shoot thinning in a procumbent cultivar is not recommended. Mechanically box pruning to a $100-\mathrm{mm}$ spur height and slowing down vegetative growth by irrigating to $50 \%$ of daily evapotranspiration $\left(\mathrm{ET}_{0}\right)$ variance between fruit set and veraison have resulted in a Ravaz Index window (5 to $10 \mathrm{~kg} \cdot \mathrm{kg}^{-1}$ ) and is recommended for procumbent red wine grape cultivars for the region with similar or better berry skin phenolic accumulation than spur-pruned vines.
\end{abstract}

The San Joaquin Valley (SJV) of California leads the state in wine grape acreage and tons produced (California Department of Food and

Received for publication 20 Feb. 2013. Accepted for publication 19 Mar. 2013.

We acknowledge the American Vineyard Foundation, Bronco Wine Company Viticulture Research Chair Trust Funds, and Oxbo International Corp. for partial funding during the execution of this project. Mention of a trademark, proprietary product, or a vendor does not constitute a guarantee or warranty of the product by the California State University.

${ }^{1}$ Former Graduate Student. Current address: Grape Creek Vineyards, 10587 East U.S. Highway 290, Fredericksburg, TX 78624.

${ }^{2}$ Research Associate.

${ }^{3}$ To whom reprint requests should be addressed; e-mailkkurtural@csufresno.edu. maximum yield is paramount, balanced cropping in this region is not possible resulting in large canopies with declining yield and less than ideal fruit composition at the farm gate (Wessner and Kurtural, 2013). The declining yield in southern SJV wine grape vineyards is attributed to mechanical box pruning and irrigating to field capacity that exacerbates the excessive fruit zone shading for procumbent (drooping/trailing growth habit) cultivars (Wessner and Kurtural, 2013). This also results in mutual shading within the canopy in the current season and depresses bud fruitfulness in subsequent seasons (Sanchez and Dokoozlian, 2005).

Several studies have shown that node number per vine is a not an accurate or a precise regulator of the final crop level in vineyards (Bernizzoni et al., 2011; Geller and Kurtural, 2013; Poni et al., 2004; Terry and Kurtural, 2011). There is agreement in recent literature that attempts to balance grapevine yield with increased pruning severity fails because of the unpredictable vegetative and reproductive compensating responses from the grapevine (Bernizzoni et al., 2011; Geller and Kurtural, 2013; Kurtural et al., 2006). The compensating responses may include enhanced bursting of secondary shoots (Kurtural et al., 2006; Main and Morris, 2004) as well as more fruitful shoots stemming from latent buds on the cordon and basal buds that are not counted during balanced pruning procedures (Kurtural et al., 2006; Poni et al., 2004). Further enhancements to achieve specific yield targets are therefore achieved with shoot and cluster thinning through manual and mechanical means (Geller and Kurtural, 2013; Kurtural et al., 2006; Terry and Kurtural, 2011). However, these practices require rigorous crop estimation and maybe economically prohibitive (Kurtural et al., 2012) because their application by manual methods may increase labor operation time in the vineyard up to 50 to $60 \mathrm{~h} \cdot \mathrm{ha}^{-1}$ (Geller and Kurtural, 2013; Intrieri and Poni, 1995).

Shoot thinning in vineyards is applied when average shoot length is between 15 and $25 \mathrm{~cm}$. Smart (1988) reported optimal shoot densities to achieve desired fruit composition and wine sensory properties for cool climate viticulture. He emphasized improved canopy microclimate and function can be achieved with shoot densities of 15 to 25 shoots/m of a row depending on cultivar and location influence. Recently, Geller and Kurtural (2013) recommended a shoot density of 35 shoots $/ \mathrm{m}$ of a row with a hypocumbent (upright growth habit) cultivar to improve canopy microclimate and to achieve optimum Ravaz Index with a sustainable yield in a warm climate region (Region $\mathrm{V}$ of California). Geller and Kurtural (2013) further reported that decreasing shoot density did not provide any further benefit to canopy function. Increasing the severity of shoot thinning resulted in a lack of physiological response as a result of vegetative compensation by the grapevine generating larger leaf area by the remaining shoots on a sparsely populated canopy. Terry and Kurtural (2011) reported a shoot density of 
23 shoots/m of optimized canopy architecture and maintained yield in a Region IV vineyard with improved berry phenolic composition at the farm gate when irrigation was reduced to $50 \%$ of $\mathrm{ET}_{\mathrm{o}}$ demand between fruit set and veraison for 'Syrah' grapevine.

Although there have been various reports on comparisons of mechanical box and spur pruning as well as determination of optimal shoot density in wine grape vineyards, most of these trials were conducted in cooler climates and did not investigate the interaction between them. There are not many specific studies published on mechanical shoot thinning effects on the grapevine grown in Region $\mathrm{V}$ with a procumbent grape cultivar such as Syrah. Therefore, our study was designed to investigate how the interaction of pruning systems and mechanical shoot removal affected canopy performance, yield components, fruit phenolic composition at harvest, and production efficiency of a procumbent cultivar in a warm climate region.

\section{Materials and Methods}

\section{Vineyard description and experimental layout}

This study was conducted from 2009 to 2011 at a commercial vineyard planted with 'Syrah' grapevine on 'SO4' $(V$. berlandieri $\times$ $V$. riparia) rootstock at $2.1 \mathrm{~m} \times 3.4-\mathrm{m}$ (vine $\times$ row) spacing in north to South-oriented rows. The treatments described below were imposed in 2009. Data collection commenced in 2010 to allow the vines to adjust to mechanical manipulation. The research site was located in Kern County, CA (lat. $35^{\circ} 00^{\prime} 322^{\prime \prime}$ $\mathrm{N}$, long. $118^{\circ} 53^{\prime} 808^{\prime \prime} \mathrm{W}$, elevation $137 \mathrm{~m}$ ) and was planted in 1999 on Premier SandyLoam soil [a coarse-loamy, mixed, superactive, calcareous thermic Xeric Torriorthent (U.S. Department of Agriculture, 2011)]. The vines were trained to a bilateral cordon at $1.35 \mathrm{~m}$ with two foliage support wires at $1.70 \mathrm{~m}$ and a $20-\mathrm{cm}$ T-top. The GDD accumulation at the research site was 2566 and $2561\left(10^{\circ} \mathrm{C}\right.$ base $)$ and $404 \mathrm{~mm}$ and $178 \mathrm{~mm}$ of precipitation was received in 2010 and 2011, respectively.

The vineyard was drip-irrigated with pressure-compensating emitters spaced at $96 \mathrm{~cm}$ delivering $1.5 \mathrm{~L} \cdot \mathrm{h}^{-1}$ per emitter. The vines were supplied with $12 \mathrm{~kg} \cdot \mathrm{ha}^{-1}$ of nitrogen in each year. The vineyard was planted in a resource-limited environment and irrigation was managed uniformly, as follows: the root zone was irrigated beginning in the third week of February based on a crop coefficient $\left(\mathrm{K}_{\mathrm{c}}\right)$ of 0.2 and $80 \%$ of the daily $\mathrm{ET}_{\mathrm{o}}$, values for which were obtained from the California Irrigation Management Information System station in Arvin, CA. Irrigation was interrupted before bloom and the soil was allowed to dry down until fruit set when midday leaf water potential was below $-1.2 \mathrm{MPa}$. The midday leaf water potential was measured at solar noon (Terry and Kurtural, 2011) every $7 \mathrm{~d}$ on four fully expanded sun leaves on four vines per treatment replicate on a grid pattern of every 94th vine with a Scholander-type pressure bomb (Model 610 Pressure Chamber Instrument; PMS Instrument Co., Corvallis, OR). After fruit set, $50 \%$ of daily $\mathrm{ET}_{\mathrm{o}}$ was applied until veraison where $\mathrm{K}_{\mathrm{c}}$ was calculated to be 0.3 at fruit set to 0.8 at veraison. Irrigation was triggered when midday leaf water potential was below $-1.4 \mathrm{MPa}$ between fruit set and veraison. Starting at veraison, irrigation was applied at $80 \%$ of daily $\mathrm{ET}_{\mathrm{o}}$ with a $\mathrm{K}_{\mathrm{c}}$ of 0.8 and irrigation was triggered when midday leaf water potential was below $-1.2 \mathrm{MPa}$. Pests were managed using an integrated pest management program according to University of California guidelines (Flaherty et al., 1992). The experiment was a $2 \times 3$ factorial (two pruning systems and three shoot densities) with four replications in a randomized complete block design of 386 vine plots of which 24 were sampled based on a grid pattern of every 16th vine.

\section{Treatment application}

Pruning systems. Two pruning systems, spur pruning and mechanical box pruning, were applied. Spur-pruned vines were manually pruned to retain a target of 25 nodes per $m$ of row on two bud spurs (control). The mechanical box-pruning treatment consisted of hedging to a $100-\mathrm{mm}$ spur height with a 600-mm sprawl-pruner (Model 63700; Oxbo International, Kingsburg, CA) to a node density target of 55 nodes per $\mathrm{m}$ of row.

Shoot thinning treatments. Three shoot thinning treatments were applied mechanically at modified Eichhorn-Lorenz scale stage 17 (Coombe, 1995) with a rotary-paddle shoot thinner and a rotary-brush attachment (Model 62731; Oxbo Int. Inc., Kingsburg, CA). Shoots were thinned to target densities of 40 shoots per $\mathrm{m}$ of a row, 45 shoots per $\mathrm{m}$ of a row, or left unthinned.

\section{Canopy and vine measurements}

Shoot numbers were measured 2 weeks after bud burst and after the application of shoot density treatments as described elsewhere (Terry and Kurtural, 2011). Shoots per vine were counted by the addition of count shoots (borne from count positions greater than $5 \mathrm{~mm}$ distal to the base of the bearing surface) and non-count shoots (borne from non-count positions less than $5 \mathrm{~mm}$ distal to the base of the bearing surface and secondary shoots). The percentage contribution of count and non-count shoots to total shoots was calculated by dividing the respective shoots by the total shoots counted. Indicators of canopy microclimate variables such as leaf layer numbers and percent canopy gaps were measured as reported elsewhere by Wessner and Kurtural (2013).

The PAR transmittance through the fruiting zone was measured as follows. A ceptometer (AccuPAR-80; Decagon Devices, Pullman, WA) was placed directly above the cordon, within the fruiting zone, parallel to the vine row at the head of each vine. Four measurements were taken with the ceptometer from 24 vines per experimental unit. Ambient $P A R$ readings were taken at a height of $60 \mathrm{~cm}$ above the canopy. The remaining three measurements were taken within the fruiting zone at the head of the vine. Measurements were taken at $1200 \mathrm{GDD}\left(10{ }^{\circ} \mathrm{C}\right.$ base) at midday with $P A R$ values ranging from $\approx 1900$ to $2200 \mu \mathrm{mol} \cdot \mathrm{m}^{2} \cdot \mathrm{s}^{-1}$. The three fruiting zone PAR measurements were combined and expressed as the percentage of total ambient $P A R$ measured at midday. Leaf area per shoot and the canopy leaf area of the vine were determined at $50 \%$ veraison from 24 vines per experimental unit. Four shoots from the north and south sides of the canopy per vine for a total of eight shoots were sampled per vine at random and stored at $4{ }^{\circ} \mathrm{C}$ at $98 \%$ humidity until measured. The number of leaves was counted, and leaf area was measured with a leaf area meter (LI-3000; LI-COR, Lincoln, NE). The canopy leaf area per vine was then determined as described elsewhere by Terry and Kurtural (2011).

\section{Yield, fruit composition, and Ravaz Index assessment}

Fruit yield and cluster numbers for each treatment were measured by hand-harvesting 24 vines from each experimental unit as the fruit reached $23 \%$ total soluble solids (TSS) measured as ${ }^{\circ}$ Brix. During both years, yield was examined for distinction between marketable and unmarketable fruit (fruit displaying greater than $30 \%$ disease damage, insect herbivory or sunburn damage). However, in both years, there was no unmarketable fruit. Average cluster weight was calculated by dividing fruit yield per vine by the number of clusters harvested per vine. Ravaz Index was calculated by dividing the yield per vine by the dormant pruning weight per vine and is expressed as kilograms per kilograms. Leaf area-to-fruit ratio was calculated by dividing the leaf area of each vine by the yield per vine and was expressed as square meters per kilogram.

Fruit composition was measured at harvest. A random 100-berry sample was collected from 24 vines from each experimental unit, placed in polyethylene bags, stored on ice, and analyzed within $24 \mathrm{~h}$. Before analysis, the 100-berry sample was weighed and average berry mass was determined. The samples were then crushed by hand and the juice was placed in $100-\mathrm{mL}$ beakers. A $5-\mathrm{mL}$ sample was used to determine the percent TSS using a digital refractometer (PAL-1; Atago Co., Tokyo, Japan). Juice $\mathrm{pH}$ was determined with a glass electrode and a $\mathrm{pH}$ meter (Model XL15; Fisher Scientific, Pittsburgh, PA). Titratable acidity (TA) of each sample was determined by titrating to $\mathrm{pH} 8.2$ with $0.1 \mathrm{~N}$ sodium hydroxide using an end point titrator (Model DL 15; Mettler-Toledo International, Columbus, $\mathrm{OH}$ ) and expressed as milligrams per liter.

Samples of 20 random berries at harvest for each treatment were used to measure total iron reactive phenolics, anthocyanins, and tannins. Berry skins were removed from the pulp by hand, rinsed with tap water followed by distilled water, and blotted dry with paper 
towels. The skins were then extracted in

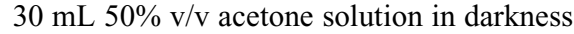
for $24 \mathrm{~h}$. Acetone was removed from samples using a rotary evaporator at 170 mbar at $30{ }^{\circ} \mathrm{C}$. Each sample was then diluted with deionized water to a final volume of $25 \mathrm{~mL}$. Total phenols, tannins, and monomeric anthocyanins were quantified spectrophotometrically (Lambda 25 ultraviolet/VIS; Perkin Elmer, Waltham, MA). Tannin content was assayed using protein precipitation (bovine serum albumin; Sigma-Aldrich, St. Louis, MO) ferric chloride reagent (Fisher Scientific), and buffer solutions (Hagerman and Butler, 1978; Harbertson et al., 2003) and quantified from a standard curve for catechin (catechin hydrate; Sigma-Aldrich). Total phenolic content was determined following a FolinCiocalteu microscale method (Waterhouse, 2002) using Folin-Ciocalteu reagent (MP Biomedicals, Solon, $\mathrm{OH}$ ) and quantified from a standard curve for gallic acid (SigmaAldrich). Total monomeric anthocyanin content was measured by $\mathrm{pH}$ differential (Giusti and Wrolstad, 2001) and quantified based on molar absorptivity and molecular weight of malvidin-3-glucoside (Indofine Chemical, Hillsborough, NJ).

\section{Statistical analyses}

Data for all parameters were tested to verify if the assumptions of analysis of variance (ANOVA) were met using Shapiro-Wilk's test. Data that failed to meet the assumptions of ANOVA were $\log 10$-transformed and analyzed using the generalized linear model (GLM) procedure in SAS (Version 9.2; SAS Institute Inc., Cary, NC). The significance level was set at $\alpha=0.05$ and means were separated using Tukey's honestly significant difference test. Shoot thinning treatments were then tested for polynomial trends across treatment levels using the GLM procedure of SAS. For the transformed data, when the ANOVA showed significant differences, the mean separation test was conducted on the transformed data but non-transformed means were presented for ease in presentation. Interactions between year and treatments were tested and whenever these interactions were significant $(P<0.05)$, analysis was conducted separately for each year.

\section{Results}

Canopy response. The total number of shoots retained was unaffected by pruning system in either year of the study (Table 1). However, the shoot thinning treatments in each year affected the number of total shoots. The number of shoots retained increased linearly in both years as the severity of shoot thinning decreased. The percentage of count and non-count shoots contributing to the total shoots was affected by year and the interaction of year and pruning systems. The contribution of count shoots to total shoots increased in 2011 when mechanical box pruning replaced spur pruning. The contribution of non-count shoots decreased from 2010 to 2011 when 40 and 45 shoots $/ \mathrm{m}$ treatments,

Table 1. Average number of total shoots per meter of row and percentage of count and non-count shoot contribution as affected by pruning and shoot thinning on 'Syrah 05/SO4'grapevine in 2010 and 2011 in Arvin, CA $(\mathrm{n}=4)$.

\begin{tabular}{|c|c|c|c|}
\hline Source of variance & $\begin{array}{l}\text { Total shoots } \\
(\text { no. } / \mathrm{m})^{\mathrm{y}}\end{array}$ & $\begin{array}{c}\text { Count } \\
\text { shoots }(\%)^{x}\end{array}$ & $\begin{array}{l}\text { Non-count } \\
\text { shoots }(\%)^{\mathrm{w}}\end{array}$ \\
\hline Pruning method ${ }^{\mathrm{z}}$ & \multicolumn{3}{|c|}{2010} \\
\hline Spur pruning & $43^{v}$ & 46 & 54 \\
\hline Mechanical box pruning & 49 & 47 & 53 \\
\hline$P>\mathrm{F}$ & 0.1956 & 0.1935 & 0.1935 \\
\hline \multicolumn{4}{|l|}{ Shoot thinning ${ }^{\mathrm{u}}$} \\
\hline 40 shoots $/ \mathrm{m}$ & $43 \mathrm{~b}$ & $46 \mathrm{~b}$ & $54 \mathrm{a}$ \\
\hline 45 shoots $/ \mathrm{m}$ & $44 \mathrm{~b}$ & $50 \mathrm{a}$ & $50 \mathrm{~b}$ \\
\hline Unthinned & $49 \mathrm{a}$ & $44 \mathrm{~b}$ & $56 \mathrm{a}$ \\
\hline$P>\mathrm{F}$ & 0.0002 & 0.0075 & 0.0005 \\
\hline \multicolumn{4}{|l|}{ Trend analysis ${ }^{t}$} \\
\hline Linear $(P)$ & 0.0001 & 0.0001 & 0.0347 \\
\hline Quadratic $(P)$ & 0.4579 & 0.5471 & 0.0214 \\
\hline Pruning method $\times$ shoot thinning $(P)$ & 0.8538 & 0.9179 & 0.8947 \\
\hline Pruning method & \multicolumn{3}{|c|}{2011} \\
\hline Spur & 55 & $57 \mathrm{~b}$ & $43 \mathrm{a}$ \\
\hline Mechanical box pruning & 55 & $78 \mathrm{a}$ & $22 \mathrm{~b}$ \\
\hline$P>\mathrm{F}$ & 0.2643 & 0.0001 & 0.2643 \\
\hline \multicolumn{4}{|l|}{ Shoot thinning } \\
\hline 40 shoots $/ \mathrm{m}$ & $36 \mathrm{~b}$ & $72 \mathrm{a}$ & $28 \mathrm{~b}$ \\
\hline 45 shoots $/ \mathrm{m}$ & $43 \mathrm{ab}$ & $69 \mathrm{~b}$ & $33 \mathrm{a}$ \\
\hline Unthinned & $55 \mathrm{a}$ & $73 \mathrm{a}$ & $27 \mathrm{~b}$ \\
\hline$P>\mathrm{F}$ & 0.0001 & 0.0022 & 0.0001 \\
\hline \multicolumn{4}{|l|}{ Trend analysis } \\
\hline Linear $(P)$ & 0.0001 & 0.0202 & 0.0471 \\
\hline Quadratic $(P)$ & 0.3258 & 0.0012 & 0.0254 \\
\hline Pruning method $\times$ shoot thinning $(P)$ & 0.0369 & 0.0494 & 0.2210 \\
\hline $\operatorname{Year}(P)$ & 0.4497 & 0.0168 & 0.0001 \\
\hline Year $\times$ pruning method $(P)$ & 0.0620 & 0.9082 & 0.0001 \\
\hline Year $\times$ shoot thinning $(P)$ & 0.1894 & 0.2617 & 0.1919 \\
\hline Year $\times$ pruning method $\times$ shoot thinning $(P)$ & 0.4421 & 0.3751 & 0.0001 \\
\hline
\end{tabular}

${ }^{\mathrm{z}}$ Spur pruning $=$ spur pruned to retain 25 nodes $/ \mathrm{m} ; 15$ Feb. 2010 and 24 Jan. 2011, mechanical box pruning: mechanically box pruned to a 10-cm hedge; 18 Feb. 2010 and 31 Jan. 2011.

${ }^{\mathrm{y}}$ Total shoots $($ no. $/ \mathrm{m})=$ count shoots $($ no. $/ \mathrm{m})+$ non-count shoots $($ no. $/ \mathrm{m})$.

${ }^{\mathrm{x}}$ Count shoots $(\%)=($ count shoots $\div$ total shoots $) \times 100$.

won-count shoots $(\%)=($ non-count shoots $\div$ total shoots $) \times 100$.

"Values with different letter designation represent significant mean separation according to Tukey's honestly significant difference test at $P \leq 0.05$.

uShoot thinning = shoots mechanically thinned to 40,45 shoots per $\mathrm{m}$ of row at Eichhorn-Lorenz stage 17 ; 13 Apr. 2010 and 18 Apr. 2011, or unthinned.

tTrend response carried to the quadratic level using single df planned orthogonal contrasts.

respectively, were applied with mechanical box pruning.

The percent $P A R$ transmittance was affected by the interaction of year, pruning system, and shoot thinning. The PAR transmittance was $100 \%$ greater with 40 shoots $/ \mathrm{m}$ treatment in 2010 when compared with the unthinned treatment in 2011. The PAR transmittance increased linearly, in both years, with the decrease in shoot density per meter of row (Table 2). The leaf layer numbers responded to pruning system and shoot thinning treatments in 2011. The leaf layer numbers were lower for mechanically boxpruned vines and increased linearly as the shoot density per meter of row increased. Pruning system did not affect canopy gaps, $P A R$, or leaf layer numbers in 2010 . There was a linear response of canopy gaps to shoot thinning treatments in 2010 where the canopy gaps decreased linearly as shoot density per meter of row increased. In 2011, mechanical box pruning increased canopy gaps compared with spur pruning. There was a linear decrease in canopy gaps with the increase in shoots per meter of row in 2011. The canopy leaf area was greater in 2011 compared with 2010. The mechanical box-pruning treatment increased leaf area by $44 \%$ compared with spur pruning in 2011. The canopy leaf area increased linearly with the increase in shoot density in 2011.

Yield components. The number of clusters harvested per vine was greater in 2011 compared with 2010 and was also affected by the interaction between pruning system and shoot thinning treatments in 2010 (Table 3). In both years, the number of clusters harvested increased linearly with the increase in shoot density per meter of row and the highest number of clusters was achieved with the combination of mechanical box pruning and unthinned treatments. The berry weight was $30 \%$ lower in 2011 compared with 2010 . Mechanical box pruning reduced berry weight in both years of the study. The berry weight declined linearly with the increase in shoot density in both years. The cluster weight at harvest was lower in 2011 compared with 2010. The pruning method affected the cluster 
Table 2. Effects of pruning method and shoot thinning on canopy architecture and microclimate of 'Syrah 05/SO4' in 2010 and 2011 in Arvin, CA ( $\mathrm{n}=4)$.

\begin{tabular}{|c|c|c|c|c|}
\hline Source of variance & $\begin{array}{c}P A R \\
\text { transmittance }(\%)^{\mathrm{y}}\end{array}$ & $\begin{array}{l}\text { Leaf layer } \\
\text { number }^{x}\end{array}$ & $\begin{array}{c}\text { Canopy } \\
\text { gaps (\%) }\end{array}$ & $\begin{array}{c}\text { Leaf } \\
\text { area/vine }\left(\mathrm{m}^{2}\right)\end{array}$ \\
\hline Pruning method ${ }^{\mathrm{z}}$ & \multicolumn{4}{|c|}{2010} \\
\hline Spur & 2.3 & 3.4 & 12.5 & 9.2 \\
\hline Mechanical box pruning & 3.0 & 3.3 & 14.6 & 11.8 \\
\hline$P>\mathrm{F}$ & 0.2855 & 0.5857 & 0.7225 & 0.1150 \\
\hline \multicolumn{5}{|l|}{ Shoot thinning ${ }^{v}$} \\
\hline 40 shoots $/ \mathrm{m}$ & $2.4 \mathrm{a}$ & 3.5 & $12.5 \mathrm{~b}^{\mathrm{u}}$ & 9.0 \\
\hline 45 shoots $/ \mathrm{m}$ & $1.8 \mathrm{~b}$ & 3.3 & $22.0 \mathrm{a}$ & 10.6 \\
\hline Unthinned & $1.2 \mathrm{~b}$ & 3.3 & $7.8 \mathrm{c}$ & 11.9 \\
\hline$P>\mathrm{F}$ & 0.0147 & 0.4058 & 0.0146 & 0.3435 \\
\hline \multicolumn{5}{|l|}{ Trend analysis ${ }^{t}$} \\
\hline Linear $(P)$ & 0.0019 & 0.4125 & 0.0012 & 0.3640 \\
\hline Quadratic $(P)$ & 0.0974 & 0.9874 & 0.2167 & 0.8235 \\
\hline Pruning method $\times$ shoot thinning $(P)$ & 0.0542 & 0.8791 & 0.4654 & 0.5489 \\
\hline Pruning method & \multicolumn{4}{|c|}{2011} \\
\hline Spur & 1.3 & $3.8 \mathrm{a}$ & $18.8 \mathrm{a}$ & $14.4 \mathrm{~b}$ \\
\hline Mechanical box pruning & 1.5 & $3.5 \mathrm{~b}$ & $27.1 \mathrm{~b}$ & $20.7 \mathrm{a}$ \\
\hline$P>\mathrm{F}$ & 0.5414 & 0.0422 & 0.0244 & 0.0002 \\
\hline \multicolumn{5}{|l|}{ Shoot thinning } \\
\hline 40 shoots $/ \mathrm{m}$ & $1.6 \mathrm{a}$ & $3.5 \mathrm{~b}$ & $26.6 \mathrm{a}$ & $14.5 \mathrm{~b}$ \\
\hline 45 shoots $/ \mathrm{m}$ & $1.4 \mathrm{a}$ & $3.6 \mathrm{~b}$ & $26.6 \mathrm{a}$ & $17.5 \mathrm{ab}$ \\
\hline Unthinned & $1.2 \mathrm{~b}$ & $3.8 \mathrm{a}$ & $15.6 \mathrm{~b}$ & $20.5 \mathrm{a}$ \\
\hline$P>\mathrm{F}$ & 0.0176 & 0.0388 & 0.0353 & 0.0094 \\
\hline \multicolumn{5}{|l|}{ Trend analysis } \\
\hline Linear $(P)$ & 0.0165 & 0.0204 & 0.0391 & 0.0001 \\
\hline Quadratic $(P)$ & 0.9128 & 0.9126 & 0.9941 & 0.8157 \\
\hline Pruning method $\times$ shoot thinning $(P)$ & 0.2323 & 0.9663 & 0.6663 & 0.0999 \\
\hline Year $(P)$ & 0.0001 & 0.0012 & 0.2214 & 0.0001 \\
\hline Year $\times$ pruning method $(P)$ & 0.6628 & 0.3953 & 0.0230 & 0.1497 \\
\hline Year $\times$ shoot thinning $(P)$ & 0.0198 & 0.0025 & 0.0565 & 0.4317 \\
\hline $\begin{array}{l}\text { Year } \times \text { pruning method } \times \\
\text { shoot thinning }(P)\end{array}$ & 0.0002 & 0.0020 & 0.2461 & 0.4497 \\
\hline
\end{tabular}

${ }^{2}$ Spur pruning $=$ spur pruned to retain 25 nodes $/ \mathrm{m}$; 15 Feb. 2010 and 24 Jan. 2011, mechanical box pruning: mechanically box pruned to a 10-cm hedge; 18 Feb. 2010 and 31 Jan. 2011.

${ }^{y} P A R$ transmittance $(\%)=$ percentage of total ambient $P A R$ measured at midday in the fruit zone. Data failed to meet assumptions of analysis of variance and were $\log 10$-transformed. For ease of presentation, non-transformed values are presented.

${ }^{\mathrm{w}}$ Canopy gaps $(\%)=$ total number of gaps divided by number of insertions. Data failed to meet assumptions of analysis of variance and were $\log 10$-transformed. For ease of presentation, non-transformed values are presented.

VValues with different letter designation represent significant mean separation according to Tukey's honestly significant difference test at $P \leq 0.05$.

"Shoot thinning $=$ shoots mechanically thinned to 40,45 shoots per $\mathrm{m}$ of row at Eichhorn-Lorenz stage 17; 13 Apr. 2010 and 18 Apr. 2011, or unthinned.

'Trend response carried to the quadratic level using single df planned orthogonal contrast.

$P A R=$ photosynthetically active radiation

weight of 'Syrah' in both years of the study. Mechanical box pruning reduced cluster weight by $13 \%$ and $5 \%$ in 2010 and 2011 , respectively. The shoot thinning treatments only affected cluster weight in 2010 when it was higher with 40 and 45 shoots $/ \mathrm{m}$ compared with the unthinned treatment. The yield per meter of row was lower in 2011 compared with 2010. Furthermore, yield per meter of row of mechanically box pruned vines declined more than the spur-pruned vines in 2011. Yield per meter of row increased linearly with the increase in shoot density per meter of row in both years of the study.

Fruit composition and berry skin phenolics. There was no interaction of year, pruning method, or shoot thinning on TSS of 'Syrah' when measured at harvest (Table 4). In 2011, there was a linear decline of TSS as the shoot density per meter of row increased, when vines subjected to the unthinned treatments were slower to reach the harvest target of $23 \%$ TSS than the 40 or 45 shoots $/ \mathrm{m}$ treatments. The juice $\mathrm{pH}$ was only affected by pruning method in 2010 when it was higher for spur-pruned vines. There was no effect of shoot thinning on juice $\mathrm{pH}$ in either year of the study. The TA of 'Syrah' was affected by year. The TA of 'Syrah' grapevine was higher in 2011 compared with 2010.

The total phenolics concentration measured in the berry skin of 'Syrah' was higher in 2011 than in 2010 (Table 4). The pruning method did not affect the total phenolics in either year of the study. There was a quadratic trend to shoot thinning where total phenolics were the lowest for 45 shoots $/ \mathrm{m}$ treatment compared with 40 shoots $/ \mathrm{m}$ or the unthinned shoot thinning treatments in both years of the study. Pruning method did not affect the anthocyanin concentration in the skin tissue of berries in either year of the study. However, there was a year and shoot thinning treatment interaction affecting anthocyanin concentration in which the anthocyanin concentration was highest in 2010 with the 40 shoots/m treatment. In both years, there was a quadratic trend of shoot thinning treatments affecting anthocyanin concentration in which the 45 shoots $/ \mathrm{m}$ treatment was the lowest compared with 40 shoots $/ \mathrm{m}$ and unthinned treatments. There was a year and shoot thinning interaction on berry skin tannin concentration. The tannin concentration was highest in 2011 with the unthinned treatment. In both years, there was a quadratic trend response to shoot thinning treatments in which tannin concentration was the lowest with the 45 shoots/m shoot thinning treatment.

Production efficiency. The pruning weight per meter of row of 'Syrah' was higher in 2011 compared with 2010, regardless of pruning system and shoot thinning combination (Table 5). The experimental year and pruning system interacted to affect the pruning weight of 'Syrah'. In both years, pruning weight of spur-pruned vines was greater than mechanically box-pruned vines. There was no effect of shoot thinning on pruning weight of 'Syrah' in either year of the study. There was an interaction of year and pruning method that affected the Ravaz Index of 'Syrah'. The highest Ravaz Index was achieved in 2010 with the mechanical boxpruning treatment. Conversely, spur pruning in 2011 resulted in the lowest Ravaz Index. In 2010, pruning system and shoot thinning treatments interacted to affect the Ravaz Index in which a combination of mechanical box pruning and unthinned treatment resulted in the highest Ravaz Index. However, this interaction was not evident in 2011. In 2011, Ravaz Index increased linearly with the increase in shoot density per meter of row. There was a year and pruning method interaction on leaf area-to-fruit ratio of 'Syrah'. The leaf area-to-fruit ratio of 'Syrah' was highest in 2010 with mechanical box pruning. It was the lowest with spur pruning in 2011. In both years of the study, there was no effect of shoot thinning treatments on leaf area-to-fruit ratio of 'Syrah'.

\section{Discussion}

Canopy response. There were no untoward weather events such as a late spring frost that would have limited the shoot numbers during the course of the trial. It must be noted that growers in southern SJV need to retain more shoots per meter of row (Geller and Kurtural, 2013; Kurtural et al., 2012) than previously reported by Smart (1985) to attain economically sustainable yield. Previous reports indicated that a combination of dormant pruning and manipulation of shoot numbers was necessary to control canopy architecture and yield in both hypo(Geller and Kurtural, 2013) and procumbent grapevine cultivars (Terry and Kurtural, 2011). Furthermore, Terry and Kurtural (2011) reported a reduction of irrigation application to $50 \%$ of daily $\mathrm{ET}_{\mathrm{o}}$ between fruit set and veraison to achieve the desired effects on canopy architecture with a procumbent cultivar 
Table 3. Effects of pruning method and shoot thinning on yield components of 'Syrah 05/SO4' in 2010 and 2011 at harvest in Arvin, CA ( $n=4)$.

\begin{tabular}{|c|c|c|c|c|}
\hline Source of variation & $\begin{array}{l}\text { Clusters harvested } \\
\text { (no./vine) }\end{array}$ & $\begin{array}{l}\text { Berry } \\
\text { wt (g) }\end{array}$ & $\begin{array}{l}\text { Cluster } \\
\text { wt }(\mathrm{g})\end{array}$ & $\begin{array}{c}\text { Yield } \\
\left(\mathrm{kg} \cdot \mathrm{m}^{-2}\right.\end{array}$ \\
\hline Pruning method ${ }^{\mathrm{z}}$ & & 2010 & & \\
\hline Spur & $68 \mathrm{~b}^{\mathrm{y}}$ & $1.31 \mathrm{a}$ & $172.7 \mathrm{a}$ & $5.4 \mathrm{~b}$ \\
\hline Mechanical box pruning & $121 \mathrm{a}$ & $1.16 \mathrm{~b}$ & $150.1 \mathrm{~b}$ & $8.5 \mathrm{a}$ \\
\hline$P>\mathrm{F}$ & 0.0001 & 0.0008 & 0.0001 & 0.0001 \\
\hline \multicolumn{5}{|l|}{ Shoot thinning ${ }^{x}$} \\
\hline 40 shoots $/ \mathrm{m}$ & $70 \mathrm{~b}$ & $1.29 \mathrm{a}$ & $171.8 \mathrm{a}$ & $5.6 \mathrm{~b}$ \\
\hline 45 shoots $/ \mathrm{m}$ & $91 \mathrm{~b}$ & $1.29 \mathrm{a}$ & $164.9 \mathrm{a}$ & $7.0 \mathrm{~b}$ \\
\hline Unthinned & $121 \mathrm{a}$ & $1.12 \mathrm{~b}$ & $150.1 \mathrm{~b}$ & $8.5 \mathrm{a}$ \\
\hline$P>\mathrm{F}$ & 0.0001 & 0.0016 & 0.0001 & 0.0012 \\
\hline \multicolumn{5}{|l|}{ Trend analysis ${ }^{\mathrm{w}}$} \\
\hline Linear $(P)$ & 0.0001 & 0.0001 & 0.0001 & 0.0001 \\
\hline Quadratic $(P)$ & 0.5725 & 0.4367 & 0.3257 & 0.1276 \\
\hline Pruning method $\times$ shoot thinning $(P)$ & 0.0001 & 0.0987 & 0.4339 & 0.0392 \\
\hline Pruning method & & 2011 & & \\
\hline Spur & $88 \mathrm{~b}$ & $1.03 \mathrm{a}$ & $117.3 \mathrm{a}$ & 4.9 \\
\hline Mechanical box pruning & $131 \mathrm{a}$ & $0.95 \mathrm{~b}$ & $111.4 \mathrm{~b}$ & 6.8 \\
\hline$P>\mathrm{F}$ & 0.0025 & 0.0001 & 0.0001 & 0.2685 \\
\hline \multicolumn{5}{|l|}{ Shoot thinning } \\
\hline 40 shoots $/ \mathrm{m}$ & $74 \mathrm{c}$ & $1.00 \mathrm{a}$ & 108.3 & $3.8 \mathrm{~b}$ \\
\hline 45 shoots $/ \mathrm{m}$ & $93 \mathrm{~b}$ & $1.01 \mathrm{a}$ & 109.8 & $4.8 \mathrm{~b}$ \\
\hline Unthinned & $131 \mathrm{a}$ & $0.95 \mathrm{~b}$ & 111.4 & $6.8 \mathrm{a}$ \\
\hline$P>\mathrm{F}$ & 0.0001 & 0.0107 & 0.7164 & 0.0001 \\
\hline \multicolumn{5}{|l|}{ Trend analysis } \\
\hline Linear $(P)$ & 0.0001 & 0.0025 & 0.6921 & 0.0001 \\
\hline Quadratic $(P)$ & 0.5781 & 0.7141 & 0.3357 & 0.2171 \\
\hline Pruning method $\times$ shoot thinning $(P)$ & 0.0715 & 0.0017 & 0.2581 & 0.3426 \\
\hline Year $(P)$ & 0.0001 & 0.0001 & 0.0001 & 0.0161 \\
\hline Year $\times$ pruning method $(P)$ & 0.0107 & 0.0566 & 0.1314 & 0.0010 \\
\hline Year $\times$ shoot thinning $(P)$ & 0.2124 & 0.3336 & 0.0006 & 0.8229 \\
\hline Year $\times$ pruning method $\times$ shoot thinning $(P)$ & 0.0027 & 0.2457 & 0.0001 & 0.4412 \\
\hline
\end{tabular}

${ }^{\mathrm{z}}$ Spur pruning $=$ spur pruned to retain 25 nodes $/ \mathrm{m} ; 15 \mathrm{Feb}$. 2010 and 24 Jan. 2011, mechanical box pruning: mechanically box pruned to a 10-cm hedge; 18 Feb. 2010 and 31 Jan. 2011.

${ }^{y}$ Values with different letter designation represent significant mean separation according to Tukey's honestly significant difference test at $P \leq 0.05$.

${ }^{\mathrm{x}}$ Shoot thinning $=$ shoots mechanically thinned to 40,45 shoots per $\mathrm{m}$ of row at Eichhorn-Lorenz stage 17; 13 Apr. 2010 and 18 Apr. 2011, or unthinned.

wTrend response carried to the quadratic level using single df planned orthogonal contrasts.

such as 'Syrah' in which contribution of noncount shoots was limited to $\approx 50 \%$ of the total shoots over the course of that study. Conversely, the GDD accumulation reported by Terry and Kurtural (2011) was $\approx 377$ GDD less than the study presented here. Mechanical shoot thinning was not effective in controlling the shoot numbers of a procumbent cultivar in Region V. This is attributed to significant vegetative compensation occurring with shoot thinning in agreement with previous studies because shoot thinning in this case led to a strong physiological impact in terms of supply and demand function at the canopy level (Bernizzoni et al., 2011). In this case, mechanical box pruning and the irrigation approach presented here were more successful in reducing the non-count shoot number contribution to the canopy architecture.

Optimum light penetration within the fruit zone will vary with the growing region and cultivar (Dokoozlian and Kliewer, 1995). Compared with a hypocumbent cultivar such as Pinot gris grown on the same single-plane trellis in the same growing region (Geller and Kurtural, 2013), the PAR transmittance of 'Syrah' in this study was almost six times less. Manipulation of shoot density resulted in a linear decrease of $P A R$ transmittance through the fruiting zone of the canopy. However, the horticultural benefit of this decrease was minimal. The optimum leaf layer number for the single-plane trellis that is commonly used in warm growing regions such as the southern SJV is between three and four (Main and Morris, 2004; Terry and Kurtural, 2011). Using either pruning system attained this leaf layer number, and the shoot thinning treatments only affected this variable in 2011. The canopy gaps measured responded in a similar fashion as the leaf layer numbers in this study. The experimental year affected leaf area more than the treatments applied. The lack of a consistent response to pruning system or shoot thinning can be attributed to vegetative compensation by the grapevine through generation of a larger leaf area with the remaining bud positions in the case of pruning systems or by the remaining shoots in the case of shoot thinning treatments. This is more evident when comparing the $12.9-\mathrm{m}^{2}$ leaf area per vine recommendation by Terry and Kurtural (2011) to achieve vine balance in which in the current study. the leaf area per vine was $\approx 30 \%$ more regardless of pruning system or shoot thinning treatment, or their combination.
Yield components. Both pruning method and shoot thinning treatments had an effect on components of yield, and shoot thinning displayed control over the components of yield as previously reported elsewhere (De Toda and Sancha, 1999; Geller and Kurtural, 2013; Kurtural et al., 2012; Terry and Kurtural, 2011). The response of number of clusters harvested was consistent with previous research demonstrating the proportional relationship between high node count and cluster numbers in mechanically box-pruned vines as reported by Bates (2008) and Poni et al. (2004). The greater number of clusters harvested per vine in mechanically box-pruned vines compared with spur-pruned vines was attributed to increased number of nodes retained and proportion of more fruitful count shoots distributed on the mechanically managed canopies as reported by Geller and Kurtural (2013). The number of clusters responded linearly to shoot thinning treatments. This response was in contrast to the quadratic trend response of contribution of count shoot percentage to the total shoot density. Berry weight was reduced with mechanical box pruning in both years of the study as reported elsewhere (Terry and Kurtural, 2011; Zabadal et al., 2002). Berry weight also responded linearly with a decrease to the concomitant increase in shoot density per meter of row as reported by Terry and Kurtural (2011). The interactions on berry weight by pruning system and shoot thinning presented in 2011 resulted in the smallest berry size with mechanical box pruning and unthinned treatment. This smaller berry size maybe preferred by winemakers, because it had the highest skinto-berry ratio (Ojeda et al., 2002). The reduction in berry weight from 2010 to 2011 was attributed to the low amount of precipitation received during the Spring of 2011. Although the same uniform irrigation management was applied in both years, the reduced amount of precipitation received in the spring of 2011 failed to fill the soil profile to desired levels to arrive at similar berry weights in successive years. The proportional increase in berry weight with declining shoot density per meter of row did not result in a proportional increase in yield as reported by Terry and Kurtural (2011). The reduction in cluster weight in 2011 compared with 2010 was also attributed to less precipitation received in 2011. Furthermore, the reduction in cluster weight with mechanical box pruning compared with spur pruning reported in this study is in line with previous studies (Bates, 2008; Geller and Kurtural, 2013; Poni et al., 2004). The smaller berry size and cluster size achieved with mechanical box pruning did not result in less yield per meter of row compared with spur pruning as reported elsewhere (Bates, 2008; DeToda and Sancha 1999; Geller and Kurtural 2013; Poni et al., 2004). This was attributed to more clusters being carried by the vine in 2011. However, in the next year, although there were more clusters carried by the mechanically box-pruned vines, the yield per meter of row was not different from spurpruned vines. This was attributed to the berry 
Table 4. Effects of pruning method and shoot thinning on berry skin phenolics of 'Syrah $05 / \mathrm{SO} 4$ ' in 2010 and 2011 at harvest in Arvin, CA $(\mathrm{n}=4)$

\begin{tabular}{|c|c|c|c|c|c|c|}
\hline Source of variation & $\begin{array}{l}\text { TSS } \\
(\%)^{y}\end{array}$ & $\begin{array}{c}\text { Juice } \\
\mathrm{pH}\end{array}$ & $\begin{array}{c}\mathrm{TA} \\
(\mathrm{mg} / \mathrm{L})^{\mathrm{x}}\end{array}$ & $\begin{array}{l}\text { Total phenolics } \\
\quad\left(\mu \mathrm{g} \cdot \mathrm{g}^{-1}\right)\end{array}$ & $\begin{array}{c}\text { Anthocyanins } \\
\left(\mu g \cdot g^{-1}\right)\end{array}$ & $\begin{array}{l}\text { Tannins } \\
\left(\mu \mathrm{g} \cdot \mathrm{g}^{-1}\right)\end{array}$ \\
\hline Pruning method ${ }^{\mathrm{z}}$ & & & & 2010 & & \\
\hline Spur & $23.7 \mathrm{a}^{\mathrm{w}}$ & $3.9 \mathrm{a}$ & 5.39 & 2360.1 & 950.3 & 1510.8 \\
\hline Mechanical box pruning & $22.6 \mathrm{~b}$ & $3.81 \mathrm{~b}$ & 5.46 & 2460.0 & 904.7 & 1578.1 \\
\hline$P>\mathrm{F}$ & 0.0166 & 0.0288 & 0.7086 & 0.6894 & 0.7617 & 0.4159 \\
\hline \multicolumn{7}{|l|}{ Shoot thinning ${ }^{v}$} \\
\hline 40 shoots $/ \mathrm{m}$ & 23.8 & 3.90 & 5.25 & $2548.0 \mathrm{a}$ & $1237.9 \mathrm{a}$ & $1749.4 \mathrm{a}$ \\
\hline 45 shoots $/ \mathrm{m}$ & 22.8 & 3.80 & 5.44 & $2170.0 \mathrm{~b}$ & $818.5 \mathrm{~b}$ & $1212.9 \mathrm{~b}$ \\
\hline Unthinned & 22.9 & 3.86 & 5.59 & $2532.6 \mathrm{a}$ & $1104.3 \mathrm{a}$ & $1540.0 \mathrm{ab}$ \\
\hline$P>\mathrm{F}$ & 0.1447 & 0.1252 & 0.2565 & 0.0240 & 0.0005 & 0.0460 \\
\hline \multicolumn{7}{|l|}{ Trend analysis ${ }^{\mathrm{u}}$} \\
\hline Linear $(P)$ & 0.1097 & 0.9954 & 0.5471 & 0.0214 & 0.0514 & 0.0471 \\
\hline Quadratic $(P)$ & 0.5547 & 0.2256 & 0.3548 & 0.0015 & 0.0001 & 0.0041 \\
\hline $\begin{array}{l}\text { Pruning method } \times \\
\text { shoot thinning }(P)\end{array}$ & 0.9857 & 0.5210 & 0.9035 & 0.0078 & 0.0016 & 0.0007 \\
\hline Pruning method & & & & 2011 & & \\
\hline Spur & $23.1 \mathrm{a}$ & 3.88 & 5.11 & 2435.8 & 930.8 & 1556.4 \\
\hline Mechanical box pruning & $22.3 \mathrm{~b}$ & 3.86 & 5.23 & 2390.7 & 809.2 & 1597.8 \\
\hline$P>\mathrm{F}$ & 0.0058 & 0.5248 & 0.4156 & 0.5698 & 0.0624 & 0.4682 \\
\hline \multicolumn{7}{|l|}{ Shoot thinning } \\
\hline 40 shoots $/ \mathrm{m}$ & $23.3 \mathrm{a}$ & 3.87 & 5.24 & $2412.8 \mathrm{a}$ & $868.6 \mathrm{a}$ & $1551.3 \mathrm{a}$ \\
\hline 45 shoots $/ \mathrm{m}$ & $22.8 \mathrm{a}$ & 3.87 & 5.00 & $2342.3 \mathrm{~b}$ & $853.7 \mathrm{~b}$ & $1544.6 \mathrm{~b}$ \\
\hline Unthinned & $21.9 \mathrm{~b}$ & 3.86 & 5.27 & $2484.5 \mathrm{a}$ & $887.7 \mathrm{a}$ & $1635.5 \mathrm{a}$ \\
\hline$P>\mathrm{F}$ & 0.0021 & 0.9042 & 0.3534 & 0.0346 & 0.0076 & 0.0353 \\
\hline \multicolumn{7}{|l|}{ Trend analysis } \\
\hline Linear $(P)$ & 0.0002 & 0.8851 & 0.2597 & 0.3524 & 0.0647 & 0.6110 \\
\hline Quadratic $(P)$ & 0.2167 & 0.2148 & 0.3548 & 0.0274 & 0.0001 & 0.0001 \\
\hline $\begin{array}{l}\text { Pruning method } \times \\
\text { shoot thinning }(P)\end{array}$ & 0.1069 & 0.0687 & 0.3145 & 0.6701 & 0.1596 & 0.6079 \\
\hline Year $(P)$ & 0.0647 & 0.4721 & 0.0224 & 0.0001 & 0.0001 & 0.0001 \\
\hline Year $\times$ pruning method $(P)$ & 0.5361 & 0.0904 & 0.7168 & 0.1884 & 0.7035 & 0.3472 \\
\hline Year $\times$ shoot thinning $(P)$ & 0.2937 & 0.1639 & 0.2769 & 0.3129 & 0.0090 & 0.0485 \\
\hline $\begin{array}{l}\text { Year } \times \text { pruning method } \times \\
\text { shoot thinning }(P)\end{array}$ & 0.4578 & 0.6574 & 0.2587 & 0.7381 & 0.9271 & 0.3826 \\
\hline
\end{tabular}

${ }^{\mathrm{z}}$ Spur pruning $=$ spur pruned to retain 25 nodes $/ \mathrm{m} 15 \mathrm{Feb} .2010$ and $24 \mathrm{Jan} .2011$, mechanical box pruning: mechanically box-pruned to a 10-cm hedge; 18 Feb. 2010 and 31 Jan. 2011.

${ }^{\mathrm{y}} \mathrm{TSS}=$ total soluble solids in juice

${ }^{\mathrm{x}} \mathrm{TA}=$ titratable acidity measured as milligrams of tartaric acid per liter of juice.

"Values with different letter designation represent significant mean separation among treatment methods according to Tukey's honestly significant difference test at $P \leq 0.05$.

'Shoot thinning $=$ shoots mechanically thinned to 40,45 shoots per $\mathrm{m}$ of row at Eichhorn-Lorenz stage 17; 13 Apr. 2010 and 18 Apr. 2011, or unthinned.

"Trend response carried to the quadratic level using single df planned orthogonal contrasts.

weight varying less than $8 \%$ between mechanically box-pruned and spur-pruned treatments in 2011 compared with $12 \%$ in 2010 . This was not enough for the yield per meter of row to be statistically different in 2011 and negated the interaction between pruning method and shoot thinning seen in 2010. Yield per meter of row increased linearly with the increase in shoot density per meter of row as reported elsewhere (Geller and Kurtural, 2013; Terry and Kurtural, 2011).

Fruit composition and berry skin phenolics. As reported elsewhere, mechanical box pruning delayed TSS accumulation compared with spur pruning in both years of the study (Morris, 2007; Terry and Kurtural, 2011). The lack of response to shoot thinning in 2010 was attributed to the higher contribution of non-count shoots to total shoots thereby negating effects of shoot thinning. Conversely, as the contribution of count shoots increased to total shoots in 2011 with the concomitant inclusion of mechanization, the TSS declined linearly as total shoot density per meter of row increased in 2011. This response is confirmed by previous reports that found that as shoot density per meter of row increased, TSS accumulation was delayed in 'Syrah' (Terry and Kurtural, 2011; Wessner and Kurtural, 2013) and in 'Pinot gris' (Geller and Kurtural, 2013). The juice $\mathrm{pH}$ of 'Syrah' was only affected in 2010 with mechanical box pruning. This was attributed to the higher crop level carried on these vines in this year. The TA of 'Syrah' did not respond any of the treatments applied. This is in contrast to report by Smart and Robinson (1991) in which an increase in leaf layers was followed by an increase in TA. However, our results are in agreement with Terry and Kurtural (2011) in which TA was unaffected by higher leaf layer numbers as a result of higher shoot density per meter of row in a warm climate.

The berry skin phenolics when measured at harvest did not respond to pruning methods applied in either year of the study. However, the increase in berry skin total phenolics in 2011 was attributed to smaller berry size witnessed in this year compared with 2010 as reported by Terry and Kurtural (2011). The quadratic response of total phenolics, anthocyanins, and tannins in which the decrease of these variables with the 45 shoots $/ \mathrm{m}$ shoot thinning treatment compared with 40 shoots $/ \mathrm{m}$ and unthinned treatments was not previously reported in literature. Terry and Kurtural (2011) reported a direct and positive response to dormant pruning and shoot density manipulation depending on the concomitant decrease of canopy leaf layers related to canopy shading affecting berry skin phenolics. They also reported an indirect but positive response to the effect of increased berry skin phenolics (a concentration effect) as a result of berry size reduction. We were able to achieve the same result in this study without the inclusion of shoot thinning. The results reported in this study confirm the vegetative compensation by sparsely populated canopies in response to shoot removal in a warm climate (Geller and Kurtural, 2013). The leaf layer numbers were unresponsive to shoot thinning treatments in 2010; and 40 and 45 shoots $/ \mathrm{m}$ treatments had similar leaf layers in the next year. Furthermore, the canopy gaps achieved by 40 and 45 shoots $/ \mathrm{m}$ treatments were also similar in 2011 thereby negating any beneficial effects of a radiation microclimate. The increased berry skin phenolics in 40 shoots $/ \mathrm{m}$ is therefore attributed to lower crop level and to a concentration effect resulting from berry size reduction in the unthinned treatment, independent of cropload as reported by Terry and Kurtural (2011).

Production efficiency. The pruning weight attained in this trial was above the recommended range for warm climate viticulture (Geller and Kurtural, 2013; Kliewer and Dokoozlian, 2005; Terry and Kurtural, 2011). However, in both years, mechanical box pruning reduced the pruning weight indicating that the crop level carried by this treatment was effective in slowing down the vegetative growth of the vines. The lack of response from any of the shoot thinning treatments in either year further emphasizes the lack of effectiveness of manipulating shoot density in Region $\mathrm{V}$ for procumbent cultivars. Shoot thinning when applied at a modified Eichhorn-Lorenz scale stage 17 sparsely populates the grapevine canopy. However, in Region V, 40 and 45 shoots $/ \mathrm{m}$ treatments repopulated the canopy rapidly with non-count shoots thereby increasing the pruning weight per meter of row at the end of the season. The Ravaz Index achieved at the end of the study was below the recommendation for the study area. Geller and Kurtural (2013) recommended that a Ravaz Index of 10 to $13 \mathrm{~kg} \cdot \mathrm{kg}^{-1}$ not only maintained yield at the economic threshold, but also maintained pruning weight per meter of row between 0.5 and $1.0 \mathrm{~kg} \cdot \mathrm{m}^{-1}$. However, this recommendation was for a cultivar used in white wine-making and attention to monomeric anthocyanin accumulation in the berry skin is of no concern. Conversely, Kliewer and Dokoozlian (2005) recommended a Ravaz Index of 5 to $10 \mathrm{~kg} \cdot \mathrm{kg}^{-1}$ while maintaining a pruning weight of 0.5 to $1.0 \mathrm{~kg} \cdot \mathrm{m}^{-1}$ for red wine grapes grown in warm climates 
Table 5. Effects of pruning method and shoot thinning on vigor, Ravaz Index, and leaf area-to-fruit ratio of 'Syrah 05/SO4' in 2010 and 2011 in Arvin, CA ( $\mathrm{n}=4)$.

\begin{tabular}{|c|c|c|c|}
\hline Source of variation & $\begin{array}{c}\text { Pruning } \\
\text { wt }(\mathrm{kg} / \mathrm{m})\end{array}$ & $\begin{array}{l}\text { Ravaz Index } \\
\left(\mathrm{kg} \cdot \mathrm{kg}^{-1}\right)\end{array}$ & $\begin{array}{l}\text { Leaf area:fruit } \\
\qquad\left(\mathrm{m}^{2} \cdot \mathrm{kg}^{-1}\right)\end{array}$ \\
\hline Pruning method ${ }^{2}$ & & 2010 & \\
\hline Spur & $0.96 \mathrm{a}^{\mathrm{y}}$ & $5.42 \mathrm{~b}$ & $1.74 \mathrm{~b}$ \\
\hline Mechanical box pruning & $0.88 \mathrm{~b}$ & $7.00 \mathrm{a}$ & $2.02 \mathrm{a}$ \\
\hline$P>F$ & 0.0093 & 0.0001 & 0.0388 \\
\hline \multicolumn{4}{|l|}{ Shoot thinning ${ }^{x}$} \\
\hline Low & 0.97 & $5.55 \mathrm{~b}$ & 1.7 \\
\hline Medium & 0.93 & $5.85 \mathrm{~b}$ & 1.8 \\
\hline High & 0.87 & $7.22 \mathrm{a}$ & 2.1 \\
\hline$P>F$ & 0.0981 & 0.0001 & 0.6009 \\
\hline \multicolumn{4}{|l|}{ Trend analysis ${ }^{\mathrm{w}}$} \\
\hline Linear $(P)$ & 0.1145 & 0.001 & 0.6547 \\
\hline Quadratic $(P)$ & 0.1245 & 0.2654 & 0.5489 \\
\hline Pruning method $\times$ shoot thinning $(P)$ & 0.5776 & 0.0035 & 0.3962 \\
\hline Pruning method & & 2011 & \\
\hline Spur & $1.3 \mathrm{a}$ & $3.71 \mathrm{~b}$ & $0.95 \mathrm{~b}$ \\
\hline Mechanical box pruning & $1.1 \mathrm{~b}$ & $4.71 \mathrm{a}$ & $1.72 \mathrm{a}$ \\
\hline$P>F$ & 0.0001 & 0.0036 & 0.0001 \\
\hline Shoot thinning & 1.2 & $3.07 \mathrm{~b}$ & 1.20 \\
\hline Low & 1.2 & $3.96 \mathrm{~b}$ & 1.45 \\
\hline Medium & 1.2 & $5.60 \mathrm{a}$ & 1.35 \\
\hline High & 0.9369 & 0.0001 & 0.5204 \\
\hline$P>F$ & 0.1110 & 0.4341 & 0.1746 \\
\hline \multicolumn{4}{|l|}{ Trend analysis } \\
\hline Linear $(P)$ & 0.9874 & 0.0001 & 0.2562 \\
\hline Quadratic $(P)$ & 0.3349 & 0.1687 & 0.5468 \\
\hline Pruning method $\times$ shoot thinning $(P)$ & 0.4457 & 0.8751 & 0.4479 \\
\hline Year $(P)$ & 0.0001 & 0.0001 & 0.0001 \\
\hline Year $\times$ pruning method $(P)$ & 0.0540 & 0.0105 & 0.0001 \\
\hline Year $\times$ shoot thinning $(P)$ & 0.1158 & 0.1806 & 0.2682 \\
\hline Year $\times$ pruning method $\times$ shoot thinning $(P)$ & 0.1562 & 0.4714 & 0.1289 \\
\hline
\end{tabular}

${ }^{\mathrm{z}}$ Spur pruning $=$ spur pruned to retain 25 nodes $/ \mathrm{m} ; 15 \mathrm{Feb}$. 2010 and 24 Jan. 2011, mechanical box pruning: mechanically box pruned to a 10-cm hedge; 18 Feb. 2010 and 31 Jan. 2011.

${ }^{y}$ Values with different letter designation represent significant mean separation according to Tukey's honestly significant difference test at $P \leq 0.05$.

${ }^{\mathrm{x}}$ Shoot thinning $=$ shoots mechanically thinned to low, medium or high thinning $(40,45$, or 55 shoots per $\mathrm{m}$ of row, respectively) at Eichhorn-Lorenz stage 17; 13 Apr. 2010 and 18 Apr. 2011.

wTrend response carried to the quadratic level using single df planned orthogonal contrasts.

such as the southern SJV. Our Ravaz Index results were in line with these recommendations in the 2010. However, in 2011, only mechanically box-pruned vines were within these guidelines. Of the shoot thinning treatments, 40 and 45 shoots $/ \mathrm{m}$ were below the Ravaz Index recommendations, indicating that they were undercropped for the amount of canopy space for which they were allocated (Terry and Kurtural, 2011). The leaf area-tofruit ratio of 'Syrah' initially indicated undercropping in southern SJV according to Kliewer and Dokoozlian (2005). The values reported for leaf area-to-fruit ratio in 2010 were in excess of 0.8 to $1.2 \mathrm{~m}^{2} \cdot \mathrm{kg}^{-1}$ reported in the literature (Geller and Kurtural, 2013; Kliewer and Dokoozlian, 2005). In 2011, spur-pruned vines saw a decline of leaf areato-fruit ratio when shoot density per meter of row increased. In that year, only the handpruned treatment with 40 shoots $/ \mathrm{m}$ approached recommended leaf area-to-fruit ratio values. This outcome was likely a growth compensation response to shoot thinning because larger leaf blades were trying to fill the sparse canopy and gain photosynthesis (Bernizzoni et al., 2011; Geller and Kurtural, 2013). It was not clear if the decline in leaf area-to-fruit ratio in 2011 was the result of canopy architecture to take advantage of the high PAR and heat accumulation in the region or distribute the excess vegetative growth by horizontally separating the canopy.

\section{Literature Cited}

Amerine, M.A. and A.T. Winkler. 1944. Composition and quality of must and wines of California grapes. Hilgardia 15:493-673.

Bates, T. 2008. Pruning level effects growth and yield of New York Concord on two training systems. Amer. J. Enol. Viticult. 59:276-286.

Bernizzoni, F., S. Civardi, M. Van Zeller, M. Gatti, and S. Poni. 2011. Shoot thinning effects on whole season photosynthesis and vine performance in Vitis vinifera L. cv. Barbera. Aust. J. Grape Wine. Res. 17:351-357.

California Department of Food and Agriculture. 2012. Grape crush report. Final 2011. Sacramento. 1 Apr. $2012<$ http://www.nass.usda.gov/ Statistics_by_State/California>.

Coombe, B.C. 1995. Adoption of a system for identifying grapevine growth stages. Austral. J. Grape Wine Res. 1:104-110.

De Toda, F.M. and J.C. Sancha. 1999. Long-term effects of simulated mechanical pruning on Grenache vines under drought conditions. Amer. J. Enol. Viticult. 50:87-90.

Dokoozlian, N.K. and W.M. Kliewer. 1995. The light environment within grapevine canopies. I. Description and seasonal changes during fruit environment. Amer. J. Enol. Viticult. 46: 209-218.

Flaherty, D.I., D.I. Christensen, and T. Lanni. 1992. Grape pest management. Univ. of California Agriculture and Natural Resources Bul. 3343 .

Geller, J.P. and S.K. Kurtural. 2013. Mechanical canopy and crop load management of Pinot Gris in a warm climate. Amer. J. Enol. Viticult. 64:65-73.

Giusti, M.M. and R.E. Wrolstad. 2001. Characterization and measurement of anthocyanins by UV-visible spectroscopy, p. F1.2.1-F1.2.13. In: Wrolstad, R.W. (ed.). Current protocols in food analytical chemistry. Wiley \& Sons, New York, NY.

vines approaching balance or a reduction of canopy leaf area as a result of less precipitation received to fill the soil profile in a dormant season. As indicated by the low Ravaz Index achieved in 2011, we conclude that the reduction in leaf area-to-fruit ratio was the result of low precipitation received, not vines actually approaching a balanced situation.

\section{Conclusions}

In the absence of a financial or a physiological incentive, shoot thinning a procumbent, red wine grape cultivar in southern SJV is not recommended. Mechanically box pruning to a 100-mm spur height and slowing down vegetative growth by differentially irrigating to $50 \%$ of daily $\mathrm{ET}_{\mathrm{o}}$ variance between fruit set and veraison in this study resulted in a Ravaz Index window recommended for red wine grape cultivars for the region with similar or better berry skin phenolic accumulation than spur-pruned vines. The 'Syrah'/'SO4' combination on the 1.35-m high, bilateral cordon training system resulted in excess vegetative growth for the study area. To distribute this excess growth, growers can either increase the trellis height to retain the single-plane, non-shoot-positioned sprawling
Gladstone, E.A. and N.K. Dokoozlian. 2003. Influence of leaf area density and trellis/training systems on the microclimate within grapevine canopies. Vitis 32:123-131.

Hagerman, A.E. and L.G. Butler. 1978. Protein precipitation method for the quantitative determination of tannins. J. Agr. Food Chem. 26:809-812. 2003. Measurement of polymeric pigments in grape berry extract and wines using a protein precipitation assay combined with bisulfate bleaching. Amer. J. Enol. Viticult. 54: 301-306.

Intrieri, C. and S. Poni. 1995. Integrated evolution of trellis training systems and machines to improve grape quality and vintage quality of mechanized Italian vineyards. Amer. J. Enol. Viticult. 46:116-127.

Kliewer, W.M. and N.K. Dokoozlian. 2005. Leaf area/crop weight ratios of grapevines: Influence of fruit composition and wine quality. Amer. J. Enol. Viticult. 56:170-181.

Kurtural, S.K., G. Dervishian, and R.L. Wample. 2012. Mechanical canopy management reduces labor costs maintains fruit composition in Cabernet Sauvignon production. HortTechnology 22:509-516.

Kurtural, S.K., B.H. Taylor, and I.E. Dami. 2006 Effects of pruning and cluster thinning on
Harbertson, J.F., E.A. Picciotto, and D.O. Adams. 
yield and fruit composition of Chambourcin grapevines. HortTechnology 16:233-240.

Main, G.L. and J.R. Morris. 2004. Leaf-removal effects on Cynthiana yield, juice composition and wine composition. Amer. J. Enol. Viticult. 55:147-152.

Morris, J.R. 2007. Development and commercialization of a complete vineyard mechanization system. HortTechnology 17:411-420.

Ojeda, H., C. Andary, E. Kraeva, A. Carbonneau, and A. Deloire. 2002. Influence of pre- and postveraison water deficit on synthesis and concentration of skin phenolic compounds during berry growth of Vitis vinifera cv. Shiraz. Amer. J. Enol. Viticult. 53:261-267.

Poni, S., F. Bernizzoni, P. Presutto, and B. Rebucci. 2004. Performance of Croatina under short-cane mechanical hedging: A successful case of adaptation. Amer. J. Enol. Viticult. 55: 379-388.

Sanchez, L. and N.K. Dokoozlian. 2005. Bud microclimate and fruitfulness in Vitis vinifera L. Amer. J. Enol. Viticult. 56:319-329.

Smart, R.E. 1985. Principles of grapevine microclimate manipulations with implications for yield and quality: A review. Amer. J. Enol. Viticult. 36:230-239.

Smart, R.E. 1988. Shoot spacing and canopy microclimate. Amer. J. Enol. Viticult. 39:325-333.

Smart, R.E. and M. Robinson. 1991. Sunlight into wine: a handbook for winegrape canopy management. Winetitles, Adelaide, Australia.

Terry, D.B. and S.K. Kurtural. 2011. Achieving vine balance of Syrah with mechanical canopy management and regulated deficit irrigation. Amer. J. Enol. Viticult. 62:426-437.
U.S. Department of Agriculture. 2011. Soil survey staff official soil series descriptions. USDANRCS. 1 Apr. 2011. <http://soils.usda.gov/ technical/classification/osd/index.html>.

Waterhouse, A. 2002. Determination of total phenolics, p. 11.1.1-11.1.8. In: Wrolstad, R.W. (ed.). Current protocols in food analytical chemistry. Wiley \& Sons, New York, NY.

Wessner, L.F. and S.K. Kurtural. 2013. Pruning systems and canopy management practice interact to affect yield and fruit composition of Syrah. Amer. J. Enol. Viticult. 64:134138.

Zabadal, T.J., G.R. Vanee, T.W. Dittmer, and R.L. Ledebuhr. 2002. Evaluation of strategies for pruning and crop control of Concord grapevines in southwest Michigan. Amer. J. Enol. Viticult. 53:204-209. 